\title{
Comparing the Effectiveness of Processing Instruction and Production-Based Instruction on L2 Grammar Learning: The Role of Explicit Information
}

\section{Adem Soruç, Jingjing Qin, YouJin Kim}

This article reports on a study that investigated whether processing instruction (PI) or production-based instruction (PBI) is more effective for the teaching of regular past simple verb forms in English. In addition, this study examined whether explicit grammatical information (EI) mediates the effectiveness of PI or PBI. A total of 194 Turkish EFL students were randomly assigned to one of the four experimental groups - PI+EI, PI-EI; PBI+EI, PBI-EI-or a control group and then completed interpretation and production tasks. The results demonstrated that (a) the PI-EI group and PBI-EI group performed equally well on both interpretation and production tasks; (b) when EI was a factor, the PI+EI group outperformed the $P B I+E I$ group on only the interpretation task, while no significant difference was found on the production task; (c) no significant differences were found between the $P I+E I$ or $-E I$ groups, and the PBI+EI or $-E I$ groups. Pedagogical implications of these findings are discussed, and suggestions made for future research.

Cet article porte sur une étude qui a voulu déterminer quelle méthode - l'instruction basée sur la compréhension et impliquant une réflexion sur le sens des formes (PI) ou l'instruction basée sur la production (PBI) - est plus efficace pour l'enseignement des formes verbales du passé en anglais. De plus, cette étude a examiné le rôle de l'information grammaticale explicite (EI) sur l'efficacité de l'instruction PI et de l'instruction PBI. Nous avons réparti, de façon aléatoire, 194 étudiants d'ALE d'origine turque à un de quatre groupes expérimentaux - PI+EI, PI-EI; PBI+EI, PBI-EI - ou à un groupe témoin. Par la suite, les étudiants ont complété des tâches d'interprétation et de production. Les résultats indiquent que : (a) le rendement du groupe PI-EI aux tâches d'interprétation et de production était aussi bon que celui du groupe PBI-EI; (b) quand l'information grammaticale explicite (EI) jouait un rôle, le rendement du groupe PI+EI aux tâches d'interprétation était supérieur à celui du groupe PBI+EI mais aucune différence significative n'a été constatée pour la tâche de production; (c) aucune différence significative $n^{\prime}$ a été constatée entre les groupes PI+EI et les groupes -EI, ni entre les groupes $P B I+E I$ et les groupes -EI. Nous discutons des implications pédagogiques de ces résultats et offrons des suggestions de recherche complémentaire.

KEYWORDS: input, output, input processing, processing instruction, explicit information 
The role of processing instruction (PI) and production-based instruction (PBI) on second language development has received a large amount of attention in the field of second language acquisition (SLA; see DeKeyser \& Botana, 2015; Shintani, 2015; Shintani, Li, \& Ellis, 2013, for comprehensive reviews). Many experimental studies have investigated VanPatten's $(1996,2004)$ input processing model and its application known as processing instruction, comparing it to a variety of different types of production-based instruction.

According to VanPatten (2004), processing is "an on-line phenomenon that takes place in working memory" (p. 7) while establishing, whether partially or completely, a connection between a form and its meaning. Although comprehensible and meaning-bearing, not all input is processed, internalized, and eventually produced. To this end, VanPatten $(1996,2004)$ suggests his model of input processing (see Figure 1). VanPatten (1996) defines input processing as "what learners do to input during comprehension - how intake is derived" (p. 7) or "how learners get form from input and how they parse sentences during the act of comprehension while their primary attention is on meaning" (VanPatten, 2002, p. 757). According to his model, processing mechanisms are strengthened by focused practice or structured input activities to ensure that the target form is processed and correct form-meaning connections are made.

To complement his input processing model, VanPatten $(1996,2004)$ developed a new pedagogical approach known as processing instruction, which is "a type of focus on form instruction that is predicated on a model of input processing" (Wong, 2004a, p. 33). VanPatten (2015) recently defined PI briefly as an intervention rather than a method that could be "designed to be used as needed" (p. 105) to help L2 learners overcome their default processing problems related to both morphological forms and syntactic features. Broadly defined, it is one means of helping L2 learners derive "better input" (Lee \& Benati, 2009, p. 38) or "richer intake from input" (Wong, 2004a, p. 33), or, as Sharwood-Smith (2015, p. 271) concisely put it, "a direct application" of input processing.

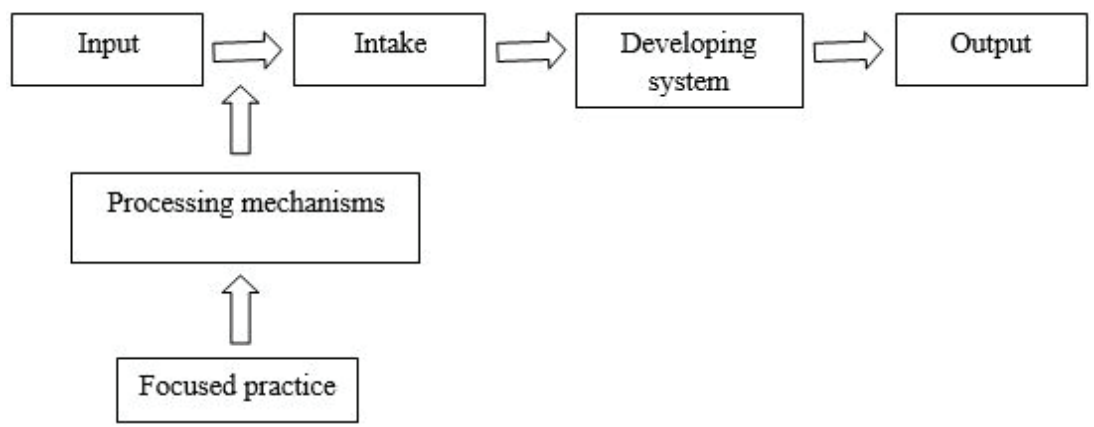

Figure 1: Processing instruction in foreign language teaching (VanPatten, 2004, p. 26) 
As a type of explicit grammar instruction, PI draws the learner's attention directly to a linguistic feature in three steps: the first component is explicit information (EI), in which learners are overtly provided metalinguistic information and rules related to the target grammatical form, for instance the regular simple past verb form (-ed) in English. The second component/step is that learners receive strategy training, for instance, related to the same morpheme. With the -ed example, they are told not to rely on temporal adverbs such as "yesterday" in the sentence but to rely on the morphological form -ed alone to make meaning. The third component is structured input, which is based on the primacy of meaning principle, in which learners never produce the targeted structure; instead, they are exposed to a series of both aural and written interpretation (comprehension) activities. No type of input activity can be called structured input unless it includes two main types of activities: referential and affective (Lee \& VanPatten, 2003). While referential activities require learners to make a correct choice between right and wrong options by focusing on the form itself, affective activities require learners either to "express an opinion, belief or some other affective response ... about the real world" (Wong, 2004a, p. 43) or to "offer opinions or indicate something about themselves" (VanPatten \& Borst, 2012, p. 272). On the other hand, PBI is "a form of explicit output practice" (Keating \& Farley, 2008, p. 640) that, like PI, consists of EI about the targeted structure and strategy training about default processing strategies. However, PBI learners, unlike learners using PI, are encouraged to produce the target form through structured output activities, so that the target form becomes salient to learners while producing it. PBI consists of referential and affective activities through which learners are encouraged to produce the correct form of the targeted structure both orally and in a written form.

\section{Processing Instruction and Production-based Instruction}

Ever since VanPatten and Cadierno (1993) published their original study, a large body of research has mushroomed comparing PI to different kinds of PBI such as traditional instruction (TI; e.g., VanPatten \& Cadierno, 1993), meaning-based output instruction (MOI; e.g., Farley, 2001), meaning-based drills instruction (MDI; e.g., Keating \& Farley, 2008), communicative output (CO; e.g., Toth, 2006) and dictogloss tasks (DG; e.g., Qin, 2008; VanPatten, Inclezan, Salazar, \& Farley, 2009). For instance, VanPatten and Cadierno's study (1993) investigated possible differences in the effectiveness of PI and TI on the acquisition of direct object pronouns in Spanish. The results showed that the PI group significantly outperformed the TI group on an interpretation task. Furthermore, although learners in the PI group were never pushed to produce the target structure in the instructional stage, they performed equally as well as those in the TI group on the production task. These results showed that PI provides a "double bonus" (VanPatten \& Cadierno, 1993, p. 54) to the learner not only in terms of processing but also for producing the targeted structure. 
Since then, a large body of research on different grammatical structures in different languages has been conducted, including Spanish preterit (past) tense (Cadierno, 1995), Spanish accusative clitics (VanPatten, Farmer, \& Clardy, 2009; VanPatten \& Fernandez, 2004; VanPatten, Inclezan, et al., 2009; VanPatten \& Sanz, 1995), Spanish subjunctive (Farley, 2001), Italian future tense (Benati, 2001), Spanish copula verbs ser and estar (Cheng, 2002), French causative (VanPatten \& Wong, 2004), English simple past tense (Benati, 2005; Benati \& Angelovska, 2015), English simple present tense (Bayrak \& Soruç, 2017), and Japanese past tense and passive constructions (Benati, 2016). All these studies found similarly that on interpretation tasks, learners exposed to PI performed significantly better than those receiving the different types of PBI mentioned above. On production tasks, however, no significant differences were found between PI and PBI. These results lend support to PI over PBI, given that learners in PI never practiced producing the targeted form in the instructional sessions.

In addition, some studies found that PI and PBI students performed equally well on the acquisition of the Spanish subjunctive (Collentine, 1998; Farley, 2004b) and English passive voice (Qin, 2008). Attributing the equal performance of the groups to the nature of the structure, these studies argued that it was the efficacy of PBI, not the ineffectiveness of PI, that enabled PBI learners to receive more "incidental input" (Farley, 2004b, p. 168) and thus to be "more PI-like than intended" (Farley, 2004b, p.167).

Not all studies in the literature, however, have found advantages of PI compared to other instructional types; this is the case for Spanish direct object pronouns and the conditional (DeKeyser \& Sokalski, 1996), Spanish direct object pronouns (Keating \& Farley, 2008; Morgan-Short \& Bowden, 2006; Salaberry, 1997), Japanese honorifics (Nagata, 1998), French causative instruction (Allen, 2000), French direct object pronouns (Erlam, 2003), Spanish anticausative clitic se (Toth, 2006), and English present subjunctive (Farley \& Aslan, 2012). All these studies, contrary to earlier PI studies, found that on the interpretation task, either the PBI and PI groups scored equally, or PBI performed better than PI; additionally, on the production task, the PBI group performed much better than PI. DeKeyser and Sokalski (1996) argued that their findings were consistent with the premise of the Skills Acquisition Theory, according to which "input practice is better for comprehension skills, and output practice for production skills" (p. 613). Additionally, Allen (2000) argued that VanPatten and Cadierno's (1993) results are "not generalizable" (p. 80) specifically to the acquisition of the French causative, claiming PI could be effective only for certain grammatical structures.

\section{Processing Instruction and Explicit Information}

Another controversial line of inquiry is related to the role of explicit information in the first and second language (McManus \& Marsden, 2017) and in PI. To investigate any possible effect of EI in PI, for instance, VanPatten and Oik- 
kenon (1996) carried out a study that compared learners receiving PI+EI (full PI), PI-EI (structured input only), and EI only. According to their results, both the PI+EI and PI-EI groups not only performed equally well over time but also scored better than the EI-only group on the interpretation and production tasks, which suggests that it is structured input, not EI, that helps learners to acquire Spanish clitic object pronouns. A large body of studies have replicated VanPatten and Oikkenon's (1996) research on different grammatical structures such as the use of de with avoir in French (Wong, 2004b), Italian future tense (Benati, 2004a), gender agreement in Italian (Benati 2004b), Spanish direct object pronouns (Fernandez, 2008; Sanz, 2004; Sanz \& MorganShort, 2004; VanPatten \& Borst, 2012; VanPatten, Collopy, Price, Borst, \& Qualin, 2013), Russian nominative/accusative case marking on nouns (VanPatten et al., 2013), and idiom learning in second language (Kim \& Nam, 2017). All these studies found that EI is not a necessary component for the greater effectiveness of PI, because whether PI was with or without EI, the groups did not outperform one another on both interpretation and production tasks.

Other replication studies were conducted on the Spanish subjunctive (Farley, 2004a; Fernandez, 2008; Russell, 2012), Spanish ser/estar copula distinction and object-verb-subject structures (Botana, 2013), German word order (e.g., Culman, Henry, \& VanPatten, 2009; Henry, Culman, \& VanPatten, 2009; VanPatten et al., 2013), German accusative case markers (Henry, Jackson, \& Dimidio, 2017), and French causative faire (VanPatten et al., 2013). All these studies found different results from those of VanPatten and Oikkenon (1996); that is, they reported a superior effect of the PI+EI group over PI-EI, thereby revealing a significant effect for EI, as well as that of structured input, in PI. In these studies, EI was found to play a facilitative role in PI, and therefore it was suggested to be beneficial in PI for different language features; this, however, depends on the nature of the tasks and the associated processing problem (Farley, 2004a; Fernandez, 2008; Henry et al., 2009). Botana (2013) also favoured the provision of EI for task-essential activities in PI, as "knowledge derived from EI-based treatments can be and often is a necessary precursor for any other more automatized knowledge to ever be possible" (p. 164).

\section{Purpose of the Current Study}

Previous research has shown that the role of EI in PI is still "open" (VanPatten \& Borst, 2012, p. 102) and "far from settled" (DeKeyser \& Botana, 2015, p. 302). As for PBI groups, according to Shintani (2015), some studies provide both EI and strategy training, while others provide only EI for PBI groups. This inconsistency also makes the role of EI in PBI unclear. Therefore, more studies are needed to measure the effectiveness of EI not only in PI but also in PBI in order to fully understand the effectiveness of PI and PBI in different conditions.

Second, it is also clear from the literature that even after more than two decades since the comparison of PI+EI to PBI+EI was first made (e.g., Benati, 
2005; VanPatten \& Cadierno, 1993), PI-EI and PBI-EI groups have not yet been compared. Such a comparison could reveal whether structured input or structured output, irrespective of EI or strategy training, is more effective on the acquisition of the target structure.

Third, PI+EI and PI-EI groups have been compared (e.g., Sanz \& MorganShort, 2004; VanPatten \& Oikkenon, 1996), and EI was not found to be as useful as structured input activities in PI. However, regarding the role of EI in PBI, given that "dismissing the potential of EI without further qualification may be too hasty" (DeKeyser \& Botana, 2015, p. 296), the comparison of PBI groups (PBI+EI vs. PBI-EI) should not be ignored. Therefore, the present study compares a PBI with EI group to a PBI without EI group in order to reveal any effects of EI. Finally, many studies have focused on written production; thus, the investigation of oral production-based tasks could shed light on the effects of PI and PBI instruction.

The main research questions addressed in this study are therefore as follows:

1. Are there any significant differences between the PI condition and the PBI condition on students' learning of the simple past -ed as measured by a sentence-level aural interpretation task? How does explicit instruction mediate the effectiveness of PI and PBI?

2. Are there any significant differences between the PI condition and the PBI condition on students' learning of the simple past -ed as measured by a sentence-level oral production task? How does explicit instruction mediate the effectiveness of PI and PBI?

\section{The Study}

\section{Setting and Selection of the Participants}

This quasi-experimental research was carried out over a period of two months at a foundation (English preparatory) school of an English-medium university in Istanbul, Turkey. Before students entered the department of their choice, they studied English as a foreign language (EFL) for a period of eight months in order to reach a satisfactory level of proficiency. At the school, learners first took the Michigan English Language Proficiency and Placement Test (2006). Of the almost 1000 learners who did not pass the proficiency test, 700 were then placed into elementary-level EFL classes, while 300 were placed into pre-intermediate and intermediate classes. Elementary was selected as the target level for this study because of elementary learners' processing difficulty in the English simple past tense marker -ed (Benati, 2005, 2016; Jiang, 2004).

After receiving approval from the school director, the elementary learners $(N=700)$ were randomly distributed into 35 classes, of which 9 were later randomly selected and assigned into 8 instructional classes ( 2 classes for 
each of the four instructional groups) and 1 control class. The initial sample consisted of 194 learners; 2 did not consent to be involved in the study and another 27 either failed to participate in the instructions or missed the assessment tests, thus leaving 165 learners for the pretest analyses. Learners' pretest scores were analyzed in order to exclude those learners with knowledge of the targeted structure; thus, another 21 learners were removed since they performed at or above $60 \%$ on both the interpretation task and the production task (e.g., Benati, 2005; Cadierno, 1995; Cheng, 2002; Russell, 2012; VanPatten \& Cadierno, 1993). After this procedure, the final sample size for the posttest analysis was $N=144$, distributed in the groups as PI+EI $(n=28)$, PI-EI $(n=32)$, PBI+EI $(n=32)$, PBI-EI $(n=36)$, and control group $(n=16)$.

\section{Instructional Materials and Implementation}

Two different material packets were developed from the students' elementary-level course books considering the principles of VanPatten $(2002,2004)$ for PI groups and the principles of Lee and VanPatten (2003) for PBI groups. All the materials were piloted to ensure for clarity of information on the worksheet. Furthermore, an EI handout was prepared, in which formal properties of the target structure were described and information about a specific input processing strategy was given. In the handout, metalinguistic information and rules of the regular verb form of English simple past tense were briefly explained, and students were warned not to rely on lexical adverbs (such as yesterday) in the sentences but instead to focus on the tense ending or morphological form -ed to establish strong form-meaning connection (see Appendix C). The EI handout was given only in the first ten minutes of the first class to the PI+EI and PBI+EI groups. The PI-EI and PBI-EI groups did not receive the EI handout; they were engaged in another task during this time (e.g., talking about their earlier class, signing the attendance list).

Packet A: PI Activities. Packet A was given to both the PI+EI and PI-EI groups. The packet consisted of 10 structured input activities: 6 referential and 4 affective. The students never produced the target form; they were only exposed to the target form through referential and affective structured input activities. The activities helped the students to receive input by both reading and listening. In the referential activities the learners chose one of the correct options focusing on the form -ed; in the affective activities, where there was no right or wrong answer, they indicated their own opinions, choosing any possible option related to their lives (see Appendix A for a sample of the activities used). In the instructional stage, the students in both groups were given feedback only by saying "Yes, correct" or "No, incorrect"; no further explicit explanations were provided.

Packet B: PBI activities. Packet B, consisting of six referential and four affective structured output activities, was prepared for the learners receiving both PBI+EI and PBI-EI. Contrary to Packet A, Packet B forced learners to produce the target structure in a meaningful and communicative context. In the refer- 
ential structured output activity, the students were given a series of pictures and regular verbs in English in order to encourage them to tell or write a story using the past form -ed of the verbs. In the affective activity, they were asked to tell or write a story using the regular verbs (see Appendix B for a sample of the activities used). There was no separate feedback session, and the students received only "Yes, correct" or "No, incorrect" on their production.

\section{Assessment Materials}

Two types of assessment tasks were used: an aural interpretation task and an oral production task (see Appendix D for sample tasks). The aural interpretation task required learners to make a choice between a right and wrong option at the time of listening, never producing the target structure (as in PI activities). It included 15 sentences in total: 10 target and 5 masking to disguise the aim of the test. The oral production task aimed to elicit learners' production level of $-e d$, and thus it forced them to produce the structure in a salient position without any temporal adverbs or time markers in the initial position of the sentence, as suggested by Lee and VanPatten (2003). It included 10 pictures and verbs to help prompt the students. The maximum possible score from both tasks was a total of 20 points when all the target items were answered correctly.

For the pretest, immediate posttest, and delayed posttest, three similar versions of both the interpretation and production task were produced and counterbalanced to avoid possible item familiarity effects and test order effects (Cheng, 2002). Answering all items in the three versions correctly would give the highest score of 60 . The number of target verbs was also controlled to balance familiar and unfamiliar words by choosing one half $(N=30)$ as the "old" verbs used in the instructional material packets and the other half $(\mathrm{N}$ = 30) as "new" verbs from other materials (such as students' course books) at the same level. The three versions were piloted, and the coefficient alpha reliability analysis found acceptable levels of internal consistency (Cronbach's alpha $.84, .83, .83$ for pretest, immediate posttest, and delayed posttest, respectively).

\section{Procedure}

Prior to the current study, a series of pilot studies were conducted with learners at different levels to decide the target level in the study. Learners at elementary, pre-intermediate, and intermediate levels were asked to talk about their past activities, and all speaking samples were recorded. Elementarylevel learners were found to rely on content or the message in the communication rather than focus on the form while interpreting and producing English simple past tense regular verb form. After the target level-elementary-was determined, the teaching of the English simple past tense was postponed until after the study was completed, to prevent students from being exposed to the target structure at least in their routine classroom hours at the time of 
the study. As the syllabus of all elementary-level classes was changed up until the end of the study, the control class was not exposed to the target structure in the classroom; they read or listened to stories and/or did grammar exercises with structures other than the target structure (present simple, present progressive, etc.).

To prevent teacher variability, only one of the researchers (the first author) taught targeted form - ed. Instructions were given in four regular classroom hours on two consecutive days for each of the instructional groups. To prevent experimenter expectancy effect and any possible bias toward one group or another, the researcher (teacher) was observed by a regular classroom teacher filling out a checklist. One week before the intervention, a pretest packet with a consent letter and a background questionnaire was given to all learners, which took no more than half an hour; one day after the intervention, an immediate posttest was given, also completed in half an hour; and three weeks after the intervention, a delayed posttest was given and completed in half an hour. As the experimental groups could not receive all the instructions in one week after the pretests, the PI groups first received treatment and the immediate posttest; in the following week, the PBI groups received the treatment.

Treatment sessions for all the groups lasted for five weeks in total. On the tests, learners first started with the aural interpretation task ( 3 minutes) and then completed the oral production task at the language laboratory of the school (5 minutes). When measuring their oral performance, learners were asked to talk into an audio recorder about the pictures on the computer screen using the related verbs next to them. Five to ten students completed the oral task at a time, in order to prevent learners from hearing each other and so that their performance was audio-recorded clearly in all the three versions of the tests. The first author transcribed the recordings together with the classroom teacher when marking the items.

\section{Scoring and Data Analyses}

In scoring the items in both interpretation and production tasks, each correct answer was given one point; as the answer of the target item was definite, there were no partially correct responses. Blank and incorrect responses (e.g., He walk home) were assigned a score of zero. In addition, pronunciation errors in the oral production task were ignored on the condition that the target structure was understandable. The highest score on each of the interpretation and the production tasks was 10, for a total of 20 maximum. The interpretation task contained masking sentences to disguise the aim of the study, but they were not scored. The first author and one of the regular classroom teachers marked the interpretation and production tasks. Some of the utterances in the oral production task were not comprehensible; this problem was resolved by repeatedly listening to the recorded audios and through discussion. The interrater agreement was $97 \%$. 
After ensuring that the data were normally distributed among all the groups, a series of statistical analyses were carried out. In order to ensure that there were no pre-existing differences among the groups before the intervention, a one-way ANOVA was performed on the pretest scores. While the analysis revealed no significant difference among the five groups on the oral production task, $F(4,144)=1.08, p=.371$, there was a significant difference among the groups on the aural interpretation task, $F(4,144)=3.18, p=.015$. To discover the reason for this difference, pairwise comparisons with a Bonferroni adjustment were conducted. The results indicated that the difference was caused by the PI-EI and PBI+EI group means $(p<.014)$. As the comparison of these two groups is not the aim of the present study, we believe these specific differences will not have an adverse impact on the study findings.

\section{Results}

\section{Results for the Aural Interpretation Task}

The aural interpretation task consisted of 10 target items. The descriptive statistics for the task are presented in Table 1 and Figure 2. The results show that all the instructional groups improved their pretest scores more than the control group, on both the immediate posttest and the delayed posttest.

Table 1

Mean Scores on the Aural Interpretation Task by Treatment Group and Time

\begin{tabular}{lrrrrrrrr}
\hline \multirow{2}{*}{$\begin{array}{l}\text { Aural Interpre- } \\
\text { tation Task }\end{array}$} & \multicolumn{2}{c}{ Pretest } & & & \multicolumn{2}{c}{ Posttest } & & \multicolumn{2}{c}{ Delayed Posttest } \\
\cline { 2 - 3 } & Mean & $S D$ & & Mean & $S D$ & & Mean & $S D$ \\
\hline PI+EI & 5.89 & 2.283 & & 8.75 & 1.43 & & 8.46 & 1.835 \\
PI-EI & 6.13 & 2.254 & & 9.25 & 1.27 & & 8.91 & 1.445 \\
PBI+EI & 4.16 & 2.641 & & 6.59 & 3.004 & & 8.84 & 1.886 \\
PBI-EI & 5.53 & 2.667 & & 8.44 & 2.063 & & 8.78 & 1.57 \\
Control & 5.00 & 2.129 & & 5.06 & 1.914 & & 5.31 & 2.056 \\
\hline
\end{tabular}

Note. PI+EI, $n=28$; PI-EI, $n=32$; PBI+EI, $n=32$; PBI-EI, $n=36$; Control, $n=16$.

To examine whether instructional types were comparable, a $5 \times 3$ factorial repeated measures ANOVA was conducted for the tests. It showed a main effect for the within-subjects variable Test, $F(2,144)=91.07, p<0.001, \eta^{2}=0.40$; a main effect for the between-subjects variable Group, $F(4,144)=12.98, p<0.001$, $\eta^{2}=0.27$; and a significant Group $\times$ Test interaction, $F(8,144)=6.35, p<0.001$, $\eta^{2}=0.15$. The Group $\times$ Test interaction is displayed visually in Figure 2.

To examine the main effect for Group, pairwise comparisons with a Bonferroni adjustment were conducted and revealed the following significant differences between groups: (a) all the instructional groups outperformed the control group; PI+EI vs. the control group $\left(M_{\text {diff }}=2.58, p=.001\right)$; PI-EI vs. the 
control group $\left(M_{\text {diff }}=2.97, p=.001\right)$; PBI+EI vs. the control group $\left(M_{\text {diff }}=1.41\right.$, $p=.05)$; PBI-EI vs. the control group $\left(M_{\text {diff }}=2.46, p=.001\right)$. (b) The only difference among the instructional groups emerged between the PI+EI and PBI+EI groups, the former outperforming the latter $\left(M_{\text {diff }}=1.17, p<.05\right)$.

To further examine the main effect for time (test), pairwise comparisons with a Bonferroni adjustment for multiple comparisons revealed the following differences: scores of all the instructional groups on the immediate posttest (Posttest 1 ) were greater than the pretest, $M_{\text {diff }}=2.28, p<.001$; and scores on the delayed posttest (Posttest 2) were greater than the pretest, $M_{\text {diff }}=2.72$, $p<.001$.

Bonferroni adjustment analysis was run for the immediate posttest, which revealed that the PI+EI group outperformed the PBI+EI group, $M_{\text {diff }}=2.16, p$ $<$.001. In addition, the PBI-EI group also performed better than the PBI+EI group, $M_{\text {diff }}=1.85, p<.05$. Finally, all groups except for the PBI+EI performed better than the control group: PI+EI vs. the control group, $M_{\text {diff }}=3.69, p<.001$; PI-EI vs. the control group, $M_{\text {diff }}=4.19, p<.001 ;$ PBI-EI vs. the control group, $M_{\text {diff }}=3.38, p<.001$.

According to the Bonferroni adjustment analysis for the delayed posttest, all the instructional groups performed equally well and better than the control group: PI+EI vs. the control group, $M_{\text {diff }}=3.15, p<.001$; PI-EI vs. the control group, $M_{\text {diff }}=3.59, p<.001$; PBI+EI vs. the control group, $M_{\text {diff }}=3.53$, $p<.001$; PBI-EI vs. the control group, $M_{\text {diff }}=3.47, p<.001$. A summary of the findings is displayed in Table 2.

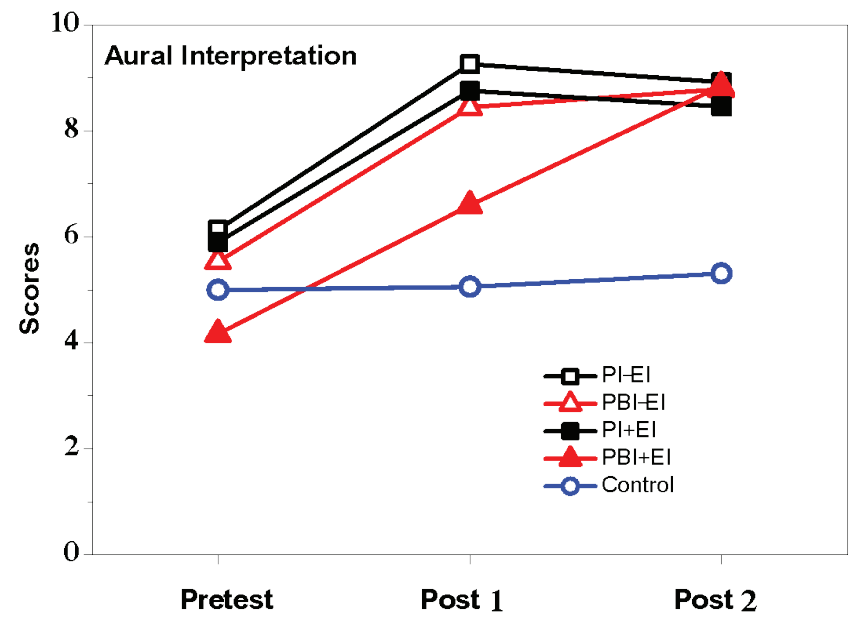

Figure 2: Group $\times$ Test interaction on the aural interpretation task. 
Table 2

Summary of Comparisons Between Treatment Groups

on the Aural Interpretation Posttests

\begin{tabular}{lrrlr}
\hline \multicolumn{1}{c}{ Posttest 1 } & $p$ & & \multicolumn{2}{c}{ Posttest 2 } \\
\cline { 5 - 5 } Comparison & $p$ & & Comparison & $<0.001$ \\
\hline $\mathrm{PBI}-\mathrm{El}>\mathrm{PBI}+\mathrm{El}$ & $<0.05$ & & $\mathrm{Pl}+\mathrm{El}>$ Control & $<0.001$ \\
$\mathrm{PI}+\mathrm{El}>\mathrm{PBI}+\mathrm{El}$ & $<0.05$ & $\mathrm{PI}-\mathrm{El}>$ Control & $<0.001$ \\
$\mathrm{PI}+\mathrm{El}>$ Control & $<0.001$ & $\mathrm{PBI}+\mathrm{El}>$ Control & $<0.001$ \\
$\mathrm{PI}-\mathrm{El}>$ Control & $<0.001$ & $\mathrm{PBI}-\mathrm{El}>$ Control &
\end{tabular}

\section{Results for the Oral Production Task}

The oral production task similarly included 10 target items. The descriptive statistics for the task appear in Table 3. This table clearly displays that although all the groups started at a very low level of the target structure, they improved their pretest scores more than the control group at the time of the immediate posttest and had maintained the improvement at the time of the delayed posttest.

Table 3

Mean Scores on the Oral Production Task by Treatment Group and Time

\begin{tabular}{|c|c|c|c|c|c|c|}
\hline \multirow{2}{*}{$\begin{array}{l}\text { Oral Production } \\
\text { Task }\end{array}$} & \multicolumn{2}{|c|}{ Pretest } & \multicolumn{2}{|c|}{ Posttest } & \multicolumn{2}{|c|}{ Delayed Posttest } \\
\hline & Mean & $S D$ & Mean & $S D$ & Mean & $S D$ \\
\hline $\mathrm{Pl}+\mathrm{El}$ & 0.82 & 2.29 & 5.21 & 4.46 & 6.04 & 4.63 \\
\hline PI-El & 1.28 & 2.40 & 6.75 & 4,38 & 7.53 & 3.65 \\
\hline $\mathrm{PBI}+\mathrm{El}$ & 0.78 & 2.09 & 6.28 & 3.69 & 5.56 & 4.16 \\
\hline PBI-EI & 0.33 & 0.86 & 6.81 & 3.82 & 7.44 & 3.33 \\
\hline Control & 0.63 & 1.26 & 2.88 & 4.21 & 1.88 & 3.76 \\
\hline
\end{tabular}

Note. PI+EI, $n=28$; PI-EI, $n=32$; PBI+EI, $n=32$; PBI-EI, $n=36$; Control, $n=16$.

The analysis of a $5 \times 3$ factorial repeated measures ANOVA found a significant main effect for the within-subjects variable Test, $F(2,144)=120.32$, $p<0.001, \eta^{2}=0.46$; a main effect for the between-subjects variable Group, $F$ $(4,144)=5.72, p<0.001, \eta^{2}=0.14$; and an interaction effect between Time $\times$ Group, $F(8,144)=3.43, p<0.001, \eta^{2}=0.09$. The Group $\times$ Test interaction is displayed visually in Figure 3.

In order to further examine the group differences, pairwise comparisons with a Bonferroni adjustment were conducted. All four of the instructional groups scored higher than the control group, PI+EI vs. the control group 
$\left(M_{\text {diff }}=2.23, p=.05\right)$; PI-EI vs. the control group $\left(M_{\text {diff }}=3.40, p=.001\right)$; PBI+EI vs. the control group $\left(M_{\text {diff }}=2.42, p=.05\right)$; PBI-EI vs. the control group $\left(M_{\text {diff }}\right.$ $=3.07, p=.05$ ). There were no statistically significant differences among the instructional groups on the oral production task.

For the significant main effect for time (test), pairwise comparisons with a Bonferroni adjustment was conducted. All the instructional groups scored higher on the immediate posttest (Posttest 1) than they did on the pretest, $M_{\text {diff }}$ $=4.82, p<.001$, and they similarly produced more accurately on the delayed posttest (Posttest 2) than they did on the pretest, $M_{\text {diff }}=4.92, p<.001$.

The results of the Bonferroni adjustment analysis for Posttest 1 revealed that (a) no significant differences were obtained among the instructional groups on the oral production task - all performed equally well; and (b) Only PI-EI and PBI-EI performed significantly better than the control group: PI-EI vs. the control group, $M_{\text {diff }}=3.88, p<.05$; PBI-EI vs. the control group, $M_{\text {diff }}=$ $3.93, p<.05$. At Posttest 1 , no other significant contrasts were found.

According to the results of the Bonferroni adjustment analysis for Posttest 2 , all the instructional groups outperformed the control group: PI+EI vs. the control group, $M_{\text {diff }}=4.16, p<.05$; PI-EI vs. the control group, $M_{\text {diff }}=5.66, p<$ .001 ; PBI+EI vs. the control group, $M_{\text {diff }}=3.69, p<.05$; PBI-EI vs. the control group, $M_{\text {diff }}=5.57, p<.001$. No other significant contrasts were found among the groups. A summary of the findings is displayed in Table 4.

The results generally showed that both structured input with or without EI and structured output with or without EI improved students' L2 grammar knowledge of the English simple past tense morpheme -ed. The study also found that explicit information plays a partial role in processing instruction: explicit information mediated the PI group to outperform the PBI group on

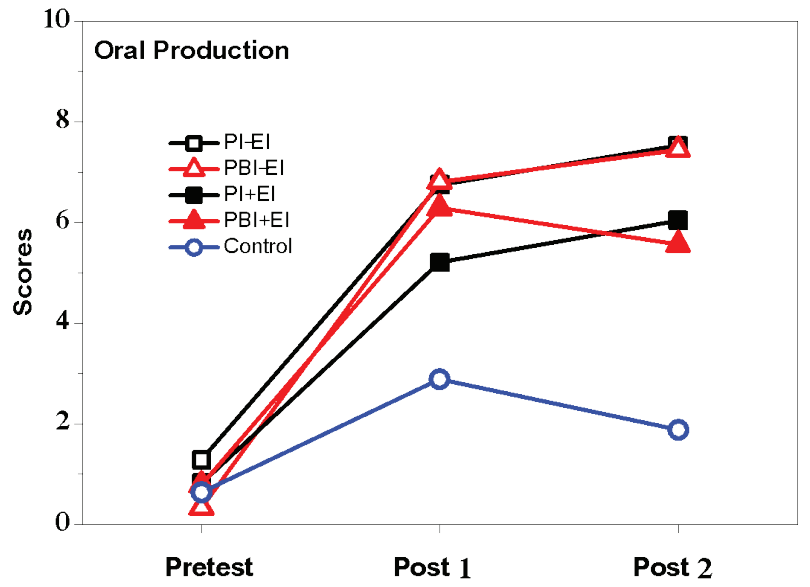

Figure 3: Group $\times$ Test interaction on the oral production task 
the interpretation task, but not on the production task. Thus the role of EI, especially in processing instruction, was found to be important when PI and PBI groups were compared. On the other hand, EI was not found to be influential when PI or PBI groups were compared to one another within the groups (i.e., the comparison of PI+EI to PI-EI, or the comparison of PBI+EI to PBI-EI).

Table 4

Summary of Comparisons Between Treatment Groups

on the Oral Production Posttests

\begin{tabular}{|c|c|c|c|}
\hline \multicolumn{2}{|c|}{ Posttest 1} & \multicolumn{2}{|c|}{ Posttest 2} \\
\hline Comparison & $p$ & Comparison & $p$ \\
\hline $\mathrm{PI}-\mathrm{EI}>$ Control & $<0.05$ & $\mathrm{PI}+\mathrm{El}>$ Control & $<0.05$ \\
\hline \multirow[t]{3}{*}{ PBI-EI > Control } & $<0.001$ & PI-EI > Control & $<0.001$ \\
\hline & & $\mathrm{PBI}+\mathrm{El}>$ Control & $<0.05$ \\
\hline & & PBI-EI > Control & $<0.001$ \\
\hline
\end{tabular}

\section{Discussion}

For the first research question, the current study compared the role of PI and PBI in students' learning of the simple past -ed as measured by a sentencelevel aural interpretation task. It further aimed to find out how EI mediates the effectiveness of PI and PBI on the same task.

According to the results of the interpretation task, the four instructional groups performed significantly better than the control group and the comparison of PI+EI group to PI-EI showed no significant difference; that is, both PI conditions had equal scores on the tasks, whereas PBI-EI performed significantly better than PBI+EI group only on the immediate posttest but not on the delayed posttest. This result shows that the presence of EI was not found to affect PI, whereas when EI was not included, the PBI-EI group performed significantly better than the PBI+EI group.

As for a comparison of the PI condition and the PBI condition, when EI was not a factor, learners in PI group (PI-EI) scored equally as well as those in the PBI group (PBI-EI), not only on the immediate posttest but also on the delayed posttest after a three-week period. In other words, structured input and structured output both had a positive effect on students' interpretation and production of the target form. On the other hand, a significant difference was discovered when EI was added as a component in the instructional sequence: learners in PI+EI performed better than those in PBI+EI in the immediate posttest, although they did not retain the improved performance after a threeweek period on the delayed posttest. Therefore, contrary to findings of earlier studies in the literature (e.g., among many others, VanPatten \& Fernandez, 
2004; VanPatten \& Sanz, 1995), this study found that the higher scores of the PI+EI group over PBI+EI on the interpretation task (in the immediate posttest at least) was not only due to structured input (given that PI-EI and PBI-EI groups made equal gains), but also because of the beneficial and facilitative effect of explicit grammatical explanation for the PI group: EI mediated for the greater effectiveness of PI than PBI on the interpretation task.

Some earlier PI studies (for instance, Culman et al., 2009; Fernandez, 2008; Henry et al., 2009; VanPatten et al., 2013) had also compared PI+EI to PI-EI groups, and all found that the effect of EI depended on the nature and complexity of the structure. For example, "EI was beneficial for the correct processing of the subjunctive" (Fernandez, 2008, p. 595), "explicit information speeds up the processes underlying acquisition" (Culman et al., 2009, p. 28), and "EI does have a facilitative effect for L2 German learners with PI" (Henry et al., 2009, p. 571). VanPatten et al. (2013) similarly argued that EI is likely to produce different effects "depending on the intersection of the processing problem and the particular structure" (p. 509). When comparing PI and PBI conditions with and without EI, this study likewise found the equal importance of EI to that of structured input activities on the interpretation task at least immediately after the instruction, as the PI+EI group performed better than the PBI+EI group, while the PI-EI group performed as equally well as the PBI-EI group. This finding can help understand the mediating role of EI in PI, especially when the nature and level of the complexity of the structure (e.g., -ed) are compared to the earlier PI studies (e.g., VanPatten et al., 2013).

The second research question aimed to find out whether there were any significant differences between the PI condition and PBI condition on students' learning of the simple past -ed when measured by an oral production task and how explicit instruction mediates the effectiveness of PI and PBI on the production task. The results showed that the four instructional groups performed better than the control group and that all the instructional groups improved their pretest scores equally well on both the immediate and the delayed posttest. This result showed that although learners in PI conditions with and without EI were never exposed to any type of production-based activities, they produced equally as well as those in PBI conditions with and without EI. Supporting the results of VanPatten and Cadierno's (1993) study, this finding suggests that PI as a direct intervention, as in VanPatten's model, can provide a way for "better processing of input and knowledge that is apparently also available for production" (VanPatten \& Cadierno, 1993, p. 54) and an "opportunity to interpret the meaning-form relationship correctly without any practice in producing the targeted form or structure" (Lee \& Benati, 2009, p. 75). In other words, as in the earlier studies (e.g., VanPatten \& Oikkenon, 1996, among many others), when PI conditions with and without EI were compared on the production task, they performed equally well over time. That is, it was the structured input that helped learners to produce the targeted form, not the EI. In their similar research, Sanz and Morgan-Short 
(2004) found a lack of a role of EI in PI, and therefore argued that EI may not be a necessary component for PI. Or, as Doughty (2004) put it, the inclusion could be superfluous when one wants to draw attention to form.

Similarly, when PBI conditions with and without EI were compared on the production task, it was found that the greater improvement was likewise not because of EI but because of structured output activities. Put another way, structured output activities helped learners to notice, interpret, and produce the target complex structure as they were pushed to produce the form in the instructional stage. As both PBI-EI and PBI+EI groups performed equally well over time from the pretest to the delayed posttest, it can then be argued that the grammatical structure itself was found by the learners to be essential in referential and affective structured output activities. Additionally, as Loschky and Bley-Vroman (1993) suggest, the activities formed the "essence of what is being attended to" (p. 139) while producing the structure. That is, when learners were pushed to produce comprehensible output in meaningful communicative activities regardless of exposure to EI, they could "crack the code" (Ellis, 1984, p. 95), they could make form-meaning connections, and they could produce the targeted form equally well.

\section{Implications}

This study focused on the comparative effectiveness of processing instruction and production-based instruction. It also sought to reveal any mediating role of explicit information on the effectiveness of PI and PBI. Although an important role for EI was found when PI and PBI groups were compared, with superior performance of PI over PBI, no role of EI was found when PI with EI was compared to PI without EI or when PBI with EI was compared to PBI without EI.

When considering these results, some interesting theoretical, methodological, and pedagogical implications can arise for L2 teachers in both EFL and ESL contexts. Theoretically, concerning any role of EI in L2 grammar, this study showed that EI mediates for the greater effectiveness of PI over PBI on the interpretation task in the immediate posttest. Therefore, this finding suggests the benefits of EI in processing instruction compared to PBI on students' learning of the simple past tense morphology on the interpretation task. According to DeKeyser and Botana (2015), it is the task-essentialness of structured input activities or "incomplete learning of the EI" (p. 301) that determines any role of EI in PI. Therefore, they suggest regular provision of EI throughout the instructional stage, not just at the beginning of the treatment as in many PI studies. Botana (2013) likewise argued that when EI is repeatedly provided to students with task-essential structured input activities, EI produces "more robust and more durable" gains (p. 163).

In terms of production, however, all four instructional groups showed equal performance. Put simply, although EI plays a facilitative role in helping L2 learners to interpret form-meaning relationships, it does not help learners 
to produce the targeted form. Therefore, English teachers could give metalinguistic explanations related to grammatical forms, but they should consider the possibility that explanation may not take their learners up to the desired production level. This study did not include a fifth instructional group (EI only), but future studies could compare PI (+EI/-EI) and PBI (+EI/-EI) groups to an EI-only group to find out whether EI alone can improve students' progress as much as either PI or PBI can.

Methodologically, this study investigated the role of EI on L2 grammar learning not only by comparing PI-EI (structured input only) to PBI-EI (structured output only), but also by comparing structured output groups with one another (PBI+EI to PBI-EI). Future studies can extend the findings of this study by both measuring students' performance in a computer setting and exploring students' eye movements using an eye-tracker, so that cognitive and more in-depth data can be collected. Eye-tracker studies can display successful students' fixation, saccades, regressions, and gaze, and they can provide evidence related to the effectiveness of PI or PBI on the acquisition of the targeted forms.

Pedagogically, this study offers some ideas not only for EFL but also for ESL teachers. First, to teach English simple past tense regular verb form $e d$, teachers can benefit from either type of instruction (PI or PBI) as both equally help learners gain optimal processing strategies. Second, teachers can prepare materials considering PI or PBI with and without EI. However, one should bear in mind that EI plays a facilitative role in PI to outperform PBI when helping learners to interpret form-meaning connections. Consequently, given that the role of EI in PI is still being debated in the literature, teachers should not rely solely on structured input activities while preparing and using PI materials, but they can refer to EI throughout the instructional period. Third, in line with earlier PI research (e.g., VanPatten \& Cadierno, 1993, among many others), this study revealed PBI should not be viewed as the only option to encourage learners to produce the target structure -ed. Fourth, teachers can implement both PI and PBI, as learners have proven that they can sustain their improved performance for up to three weeks after exposure to both types of tasks.

\section{Conclusion}

The study reported in this article partially supports the findings of earlier PI research. The study mainly indicated that EI mediates the greater effectiveness of PI over PBI on an interpretation task, thus making PI+EI instruction more effective than PBI+EI, although no significant difference was found on a production task. Its results should be considered along with its limitations, such as a possible ceiling effect and/or lack of one more instructional group receiving EI only. Therefore, the results should be evaluated considering only the targeted structure in the study (simple past tense morpheme $-e d$ ). Fu- 
ture studies can replicate the same design with PI (+EI/-EI) and PBI (+EI/-EI) groups to find out whether explicit information plays a role in processing instruction and in production-based instruction involving students from different linguistic backgrounds.

\section{Acknowledgements}

We would like to thank Dr. Rod Ellis and Dr. Ayşe Akyel for their invaluable comments on the design of the study. We are also grateful for Meredith $\mathrm{H}$, D'Arienzo, who provided useful comments during the revision process.

\section{Authors}

Adem Soruç is an Assistant Professor in the Department of English Language and Education (TEFL) at Sakarya University in Turkey. He has worked as a postdoctoral researcher on EMI at the University of Oxford. He has published in System, ELT Journal, ELT Mag, Novitas-Royal, and Educational Sciences: Theory and Practice.

Jinging Qin is currently an Associate Professor in the Department of English and Writing Studies at Zayed University, Abu Dhabi, United Arab Emirates. She has published in Language Teaching Research, System, and TESOL Publications. She previously taught at the university level in the United States, China, and Turkey.

YouJin Kim is Associate Professor in the Department of Applied Linguistics and ESL at Georgia State University. She is co-author of Pedagogical Grammar (with Casey Keck, 2014), and has published in journals such as Studies in Second Language Acquisition, Language Learning, Modern Language Journal, Applied Linguistics, and TESOL Quarterly.

\section{References}

Allen, L. Q. (2000). Form-meaning connections and the French causative: An experiment in processing instruction. Studies in Second Language Acquisition, 22, 69-84.

Bayrak, S., \& Soruç, A. (2017). Comparative effectiveness of input-based instructions on L2 grammar knowledge: Textual enhancement and processing instruction. Sakarya University Journal of Education, 7(1), 195-208. https://doi.org/10.19126/suje.283032

Benati, A. (2001). A comparative study of the effects of processing instruction and output-based instruction on acquisition of the Italian future tense. Language Teaching Research, 5, 95-127. https://doi.org/10.1177/136216880100500202

Benati, A. (2004a). The effect of structured input activities and explicit information on the acquisition of Italian future tense. In B. VanPatten (Ed.), Processing instruction: Theory, research, and Commentary (pp. 207-226). Mahwah, NJ: Lawrence Erlbaum Associates.

Benati, A. (2004b). The effects of processing instruction and its components on the acquisition of gender agreement in Italian. Language Awareness, 13(2), 67-80. http://dx.doi. org $/ 10.1080 / 09658410408667087$

Benati, A. (2005). The effects of processing instruction, traditional instruction and meaningoutput instruction on the acquisition of the English past simple tense. Language Teaching Research, 9, 67-93. https://doi.org/10.1191/1362168805lr154oa

Benati, A. (2016). Processing instruction and the acquisition of Japanese morphology and syntax. In A. Benati \& S. Yamashita (Eds.), Theory, research and pedagogy in learning and teaching Japanese grammar (pp. 73-98). London, UK: Palgrave Macmillan UK.

Benati, A., \& Angelovska, T. (2015). The effects of processing instruction on the acquisition of English simple past tense: Age and cognitive task demands. International Review of Applied Linguistics in Language Teaching, 53(2), 249-269. https://doi.org/10.1515/iral-2015-0012 
Botana, G. P. (2013). The role of task-essentialness and explicit information in processing instruction (Doctoral dissertation, University of Maryland, College Park).

Cadierno, T. (1995). Formal instruction from a processing perspective: An investigation into the Spanish past tense. Modern Language Journal, 19, 179-193. https://doi. org/10.1111/j.1540-4781.1995.tb05430.x

Cheng, A. (2002). The effects of processing instruction on the acquisition of ser and estar. Hispania, 85, 308-323. https://doi.org/10.2307/4141092

Collentine, J. (1998). Processing instruction and the subjunctive. Hispania, 81, 576-587. https:// doi.org/10.2307/345673

Culman, H., Henry, N., \& VanPatten, B. (2009). The role of explicit information in instructed SLA: An on-line study with processing instruction and German accusative case inflections. Die Unterrichtspraxis/Teaching German, 42(1), 19-31.

https://doi.org/10.1111/j.17561221.2009.00032.x

DeKeyser, R., \& Botana, G. P. (2015). The effectiveness of processing instruction in L2 grammar acquisition: A narrative review. Applied Linguistics, 36(3), 290-305. https://doi.org/10.1093/ applin/amu071

DeKeyser, R. M., \& Sokalski, K. J. (1996). The differential role of comprehension and production practice. Language Learning, 46(4), 613-642. https://doi.org/10.1111/j.1467-1770.1996.tb01354.x

Doughty, C. J. (2004). Commentary: When PI is focus on form it is very, very good, but when it is focus on forms.... In B. VanPatten (Ed.), Processing instruction: Theory, research, and commentary (pp. 261-273). Mahwah, NJ: Lawrence Erlbaum Associates.

Ellis, R. (1984). Classroom second language development: A study of classroom interaction and language acquisition. Oxford, UK: Pergamon.

Erlam, R. (2003). Evaluating the relative effectiveness of structured-input and output-based instruction in foreign language learning. Studies in Second Language Acquisition, 25, 559-582. https://doi.org/10.1017/S027226310300024X

Farley, A. P. (2001). Authentic processing instruction and the Spanish subjunctive. Hispania, 84, 289-299. https://doi.org/10.2307/3657760

Farley, A. P. (2004a). Processing instruction and the Spanish subjunctive: Is explicit information needed? In B. VanPatten (Ed.), Processing instruction: Theory, research, and commentary (pp. 227-240). Mahwah, NJ: Erlbaum.

Farley, A. P. (2004b). The relative effects of processing instruction and meaning-based output instruction. In B. VanPatten (Ed.), Processing instruction: Theory, research, and commentary (pp. 143-168). Mahwah, NJ: Erlbaum.

Farley, A., \& Aslan, E. (2012). The relative effects of processing instruction and meaning-based output instruction on L2 acquisition of the English subjunctive. ELT Research Journal, 1(2), 120-141.

Fernandez, C. (2008). Reexamining the role of explicit information in processing instruction. Studies in Second Language Acquisition, 30, 277-305. https://doi.org/10.1017/S0272263108080467

Henry, N., Culman, H., \& VanPatten, B. (2009). More on the effects of explicit information in processing instruction: A partial replication and response to Fernandez (2008). Studies in Second Language Acquisition, 31, 359-375. https://doi.org/10.1017/S0272263109990027

Henry, N., Jackson, C. N., \& Dimidio, J. (2017). The role of prosody and explicit instruction in processing instruction. Modern Language Journal, 101(2), 294-314. https://doi.org/10.1111/ modl.12397

Jiang, N. (2004). Morphological insensitivity in second language processing. Applied Psycholinguistics, 25(4), 603-634. https://doi.org/10.1017/S0142716404001298

Keating, G. D., \& Farley A. P. (2008). Processing instruction, meaning-based output instruction, and meaning-based drills: Impacts on classroom L2 acquisition of Spanish object pronouns. Hispania, 91(3), 639-650.

Kim, J. E., \& Nam, H. (2017). The pedagogical relevance of processing instruction in second language idiom acquisition. International Review of Applied Linguistics in Language Teaching, 55(2), 93-132. https://doi.org/10.1515/iral-2015-0027 
Lee, J., \& Benati, A. (2009). Research and perspectives on processing instruction. Berlin, Germany: Mouton de Gruyter.

Lee, J. F., \& VanPatten, B. (2003). Making communicative language teaching happen. New York, NY: McGraw-Hill.

Loschky, L., \& Bley-Vroman, R. (1993). Grammar and task-based learning. In G. Crookes and S. Gass (Eds.), Tasks and language learning: Integrating theory and practice (pp. 123-167). Bristol, UK: Multilingual Matters.

McManus, K., \& Marsden, E. (2017). L1 explicit instruction can improve L2 online and offline performance. Studies in Second Language Acquisition, 39(3), 459-492. https://doi.org/10.1017/ S027226311600022X

Morgan-Short, K., \& Bowden, H. W. (2006). Processing instruction and meaningful output-based instruction: Effects on second language development. Studies in Second Language Acquisition, 28(1), 31-65. https://doi.org/10.1017/S0272263106060025

Nagata, N. (1998). Input vs. output practice in educational software for second language acquisition. Language Learning and Technology, 1, 23-40.

Qin, J. (2008). The effect of processing instruction and dictogloss tasks on acquisition of the English passive voice. Language Teaching Research, 12(1), 61-82. https://doi. org/10.1177/1362168807084494

Russell, V. (2012). Learning complex grammar in the virtual classroom: A comparison of processing instruction, structured input, computerized visual input enhancement, and traditional instruction. Foreign Language Annals, 45(1), 42-71. https://doi.org/10.1111/j.19449720.2012.01168.x

Salaberry, R. (1997). The role of input and output practice in second language acquisition. Canadian Modern Language Review, 8, 281-308.

Sanz, C. (2004). Computer delivered implicit vs. explicit feedback in processing instruction. In B. VanPatten (Ed.), Processing instruction: Theory, research, and commentary (pp. 245-59). Mahwah, NJ: Lawrence Erlbaum Associates.

Sanz, C., \& Morgan-Short, K. (2004). Positive evidence vs. explicit rule presentation and explicit negative feedback: A computer-assisted study. Language Learning, 54(1), 35-78. https://doi. org/10.1111/j.1467-9922.2004.00248.x

Sharwood-Smith, M. (2015). A commentary on processing instruction. International Review of Applied Linguistics in Language Teaching, 53(2), 271-275. https://doi.org/10.1515/iral-2015-0013

Shintani, N. (2015). The effectiveness of processing instruction and production-based instruction on L2 grammar acquisition: A meta-analysis. Applied Linguistics, 36(3), 306-325. https://doi. org/10.1093/applin/amu067

Shintani, N., Li, S., \& Ellis, R. (2013). Comprehension-based versus production-based grammar instruction: A meta-analysis of comparative studies. Language Learning, 63(2), 296-329. https://doi.org/10.1111/lang.12001

Toth, P. (2006). Processing instruction and a role for output in second language acquisition. Language Learning, 56(2), 319-385. https://doi.org/10.1111/j.0023-8333.2006.00349.x

VanPatten, B. (1996). Input processing and grammar instruction: Theory and research. Norwood, NJ: Ablex.

VanPatten, B. (2002). Processing instruction: An update. Language Learning, 52(4), 755-803. https:// doi.org/10.1111/1467-9922.00203

VanPatten, B. (2004). Input processing in SLA. In B. VanPatten (Ed.), Processing instruction: Theory, research, and Commentary (pp. 5-31). Mahwah, NJ: Lawrence Erlbaum Associates.

VanPatten, B. (2015). Foundations of processing instruction. International Review of Applied Linguistics in Language Teaching, 53(2), 91-109.

VanPatten, B., \& Borst, S. (2012). The roles of explicit information and grammatical sensitivity in the processing of clitic direct object pronouns and word order in Spanish L2. Hispania, 95(2), 270-284.

VanPatten, B., \& Cadierno, T. (1993). Explicit instruction and input processing. Studies in Second Language Acquisition, 15, 225-243. https://doi.org/10.1017/S0272263100011979 
VanPatten, B., Collopy, E., Price, J. E., Borst, S., \& Qualin, A. (2013). Explicit information, grammatical sensitivity, and the first-noun principle: A cross-linguistic study in processing instruction. Modern Language Journal, 97(2), 506-527. https://doi.org/10.1111/j.1540-4781.2013.12007.x

VanPatten, B., Farmer, J. L., \& Clardy, C. L. (2009). Processing instruction and meaning-based output instruction: A response to Keating and Farley (2008). Hispania, 92(1), 124-135.

VanPatten, B., \& Fernandez, C. (2004). The long-term effects of processing instruction. In B. VanPatten (Ed.), Processing instruction: Theory, research, and commentary (pp. 277-93). Mahwah, NJ: Lawrence Erlbaum Associates.

VanPatten, B., Inclezan, D., Salazar, H., \& Farley, A. (2009). Processing instruction and dictogloss: A study on object pronouns and word order in Spanish. Foreign Language Annals, 42(3), 557-575. https://doi.org/10.1111/j.1944-9720.2009.01033.x

VanPatten, B., \& Oikkenon, S. (1996). Explanation versus structured input in processing instruction. Studies in Second Language Acquisition, 18, 495-510. https://doi.org/10.1017/ S0272263100015394

VanPatten, B., \& Sanz, C. (1995). From input to output: Processing instruction and communicative tasks. In F. Eckman, D. Highland, P. Lee, J. Mileham, \& R. Rutkowski (Eds.), Second language acquisition: Theory and pedagogy (pp. 169-186). Mahwah, NJ: Erlbaum.

VanPatten, B., \& Wong, W. (2004). Processing instruction and the French causative: Another replication. In B. VanPatten (Ed.), Processing instruction: Theory, research, and commentary (pp. 99-120). Mahwah, NJ: Lawrence Erlbaum Associates.

Wong, W. (2004a). The nature of processing instruction. In B. VanPatten (Ed.), Processing instruction: Theory, research and commentary (pp. 33-65). Mahwah, NJ: Lawrence Erlbaum.

Wong, W. (2004b). Processing instruction in French: The role of explicit information and structured input. In B. VanPatten (Ed.), Processing instruction: Theory, research and commentary (pp. 187-206). Mahwah, NJ: Erlbaum.

\section{Appendix A: A Sample for Structured Input Activities in PI Packet}

Referential structured input activity: Listen to the following statements made by a journalist about the life of footballer David Beckham and decide whether each statement is referring to his past life as a Los Angeles Galaxy player or his present life as a retired footballer. Put an X or a tick for the correct option.

$\begin{aligned} & \text { LOS ANGELES GALAXY } \\ & \text { (PAST) }\end{aligned}$
$\begin{aligned} & \text { 1. } \\ & 2 .\end{aligned}$
RETIRED
(NOW)

Affective structured input activity: Read the phrases about a group of students and their past activities and indicate whether they happened in your school. Circle True or False.

1. We enjoyed a summer picnic.
a) True
b) False

2. We visited the library.
a) True
b) False
(8 more items) 


\section{Appendix B: A Sample for Structured Output Activities in PBI Packet}

Referential structured output activity: You will be given a series of pictures which come from a local newspaper in London. They show a story about Robin in the past. Write/tell his story using the verbs given.

1. Robin / stop

2. woman / call for help

(8 more items)

Affective structured output activity: Write/tell what you did in your school last semester. Use the following verbs/nouns:

enjoy a summer picnic

work in the garden

visit the library exercise together paint the walls organize a day trip

\section{Appendix C : Explicit Grammatical Information Handout}

We use Simple past tense to talk about finished actions in the past.

We add $-e d,-d$, or $-i e d$ to the end of the verb to make the past simple of most verbs.

E.g., Last night he stayed in a hotel.

E.g., He prepared breakfast two hours ago.

E.g., She studied English last year.

$>$ When you use the Simple past tense to refer to finished actions in the past, you can also find some time-related phrases or temporal adverbs such as in the examples above: yesterday two hours ago last year

HOWEVER:

Always pay attention to the end of the verb to understand its pastness because you can sometimes hear or read a sentence without temporal adverbs (e.g., he walked home).

When you read or listen, you must rely on the tense ending to understand whether the event happened in the past.

\section{Appendix D: A Sample of the Activities Used in Assessment Tasks}

Aural Interpretation Task: The comparative statements below come from a British magazine about Mr. Bean's present life and Charlie Chaplin's past life. Listen to their story and decide whether the statement is referring to Mr. Bean or Charlie Chaplin.

Mr. Bean

(NOW)

1.

2.

Sentences heard:

1. He appeared in music halls.

2. He is studying for his Master's degree at Oxford.

(13 more with masking sentences)

Oral Production Task: Tom went parachuting. You will see some pictures below to learn about Tom's past activities. Look at the pictures and talk about what he did using the verbs given.

Actions before and after parachuting

1. want to relax

2. jump down

(8 more items) 